\title{
The Ethyl Acetate Fraction of Torbangun (Coleus amboinicus L.) Leaves Increasing Milk Production with Up-Regulated Genes Expression of Prolactin Receptor
}

\author{
Ade Chandra Iwansyah ${ }^{1 *}$, Rizal Martua Damanik ${ }^{2}$, Lilik Kustiyah ${ }^{2}$, Muhammad Hanafi ${ }^{3}$ \\ ${ }^{1}$ Research Center for Appropriate Technology, Indonesian Institute of Sciences, Subang 41213, Indonesia \\ 2 Department of Community Nutrition, Faculty of Human Ecology, Bogor Agricultural University, Bogor 16680, \\ Indonesia \\ ${ }^{3}$ Research Center for Chemistry, Indonesian Institute of Sciences, South Tangerang 15320, Indonesia
}

Article history:

Submission October 2018

Revised November 2018

Accepted April 2019

*Corresponding author:

E-mail:

chandra.iwansyah@gmail.com

\begin{abstract}
This study is aimed towards determining the lactagogue effect of torbangun leaves on lactogenic hormone plasma levels and on the expression of their receptors in mammary glands of lactating rats. Lactagogue activity was evaluated by volume of milk was produced by the rats treated with commercial milk booster containing 'katuk' leaves extract (AF), ethyl acetate fraction of torbangun leaves (EA), water extraction of torbangun leaves (AQ) and kaempferol (KP). Lactating rats $(n=5)$ of Sprague dawley with six pups were fed with AF, EA, AQ, and KP in the amount of $50 \mathrm{mg} / \mathrm{kg}, 30 \mathrm{mg} / \mathrm{kg}, 80 \mathrm{mg} / \mathrm{kg}$ and $60 \mathrm{mg} / \mathrm{kg}$ body weight, respectively. The volume of milk was estimated by the increment in pup weight after breastfed. The levels of serum lactogenic hormones were determined by ELISA methods. To access the expression level of lactogenic hormone's receptors in the mammary gland real time - polymerase chain reaction method was employed. The results showed that ethyl acetate fraction of torbangun leaves (EA) (a) was not significantly stimulating the synthesis of serum prolactin and estradiol at day 14 and day 28 lactation period, (b) down-regulated the gene expression of estradiol receptor (ER $\alpha$ ) at day 28 , and (c) up-regulated the gene expression of prolactin receptor (PRLR) in mammary gland at day 14 and day 28. This study suggests that ethyl acetate fraction of torbangun leaves was induced milk production, by up-regulating the gene expression of prolactin receptor (PRLR) in the mammary gland of lactating rats.
\end{abstract}

Keywords: Coleus amboinicus L., lactogenic hormones, genes expression, lactagogue, milk booster, torbangun

\section{Introduction}

The mothers have many reasons that were not given exclusive breastfeeding (0-6 month) to the baby; one of them is limited of breast milk production. Milk production may be affected by nutritional factors and endocrine factors [1]. Lactagogue herbs such as Coleus amboinicus Lour have been suggested as an alternative to solve the limitation of milk production [2, 3].

Torbangun leaves (C. amboinicus L.), Lamiaceae family, an indigenous Indonesian herbal medicine, has been reported to have potential of increasing breast milk production [4]. The extracts of torbangun leaves and its fraction contained phytochemical content, viz., terpenoids, phenolic, flavonoids and ester groups [5, 6, 7]. Some of the flavonoids can bind to estrogen receptors (ER) can affect ER regulation, metabolism and estrogen synthesis, and apoptosis. Flavonoids that have estrogen-like activity are known as "phytoestrogens" [8]. Phytoestrogens had similarities in chemical structure with estradiol, which can bind to alpha and beta estrogen receptors $[9,10]$.

Prolactin has an important role in the develop-

\section{How to cite:}

Iwansyah AC, Damanik RM, Kustiyah L, Hanafi M (2019) The Ethyl Acetate Fraction of Torbangun (Coleus amboinicus L.) Leaves Increasing Milk Production with Up-Regulated Genes Expression of Prolactin Receptor. Journal of Tropical Life Science 9 (2): 147 - 154. doi: 10.11594/jtls.09.02.03 
ment of mammary glands during early gestation until postpartum [11]. The interaction of prolactin and its receptor on the membrane epithelial cell (MEC) of the mammary gland determine the amount of milk production so that the presence of prolactin receptor (PRLR) was required for the expression of milk protein during lactation [12]. PRLR plays a role in activating the Janus kinase pathway (Jak2), by activating STAT-5 which is required for lactogenesis processes during pregnancy and lactation to occur [13]. Estradiol plays an important role in the regulation of prolactin. As published by [14], estradiol may increase the concentration of prolactin mRNA, by increasing the transcription of the prolactin gene, in the hypothalamus. Estradiol receptors (ER) play a role in the regulation of tryptophan hydroxylase enzymes, where it is known that tryptophan is a neurotransmitter precursor of serotonin [15, 16]. Moreover, the other plausible mechanisms involved in increasing milk production can be by up-regulation of oxytocin receptor gene and protein in the anterior pituitary [17].

Torbangun leaves and their interaction with lactagogue have been widely demonstrated; although there is lack of evidence explaining the mechanisms by which lactagogue compounds act against lactogenic hormones and their receptors. In our previous studies, ethyl acetate fraction of torbangun leaves showed potent antioxidant activities and increasing milk production in lactating rats [6,7]. Hence, the present work is aimed to determine the lactagogue effect of torbangun leaves to plasma levels of lactogenic hormones and gene expression of their receptors in mammary glands of lactating rats.

\section{Material and Methods \\ Reagents and materials}

Torbangun leaves (C. amboinicus L.) were collected from the Sukabirus garden, Megamendung Bogor, Indonesia ("S 06 39'58.3"; "106²52'28.7"; $558 \mathrm{mdpl}$ ). The cutting interval of torbangun leaves were 60 days, each cutting was cultivated with $25 \mathrm{~cm}$ radius from the other, and taken $15 \mathrm{~cm}$ from the end of each branch [18,19]. Botanical authentication was performed by the botanist from "Herbarium Bogorienses", Research Center for Biology, Indonesian Institute of Sciences, where the voucher specimen has been deposited (No.145/IPH.1.01/II.8/II/2015).
The materials of research were ethanol, ethyl acetate, n-hexane, phosphate buffer saline (PBS), distilled water and agarose gel. Experimental animals used pregnancy female rats (Sprague dawley strain), is approximately four months old, which obtained from PT. Indoanilab, Bogor-Indonesia.

\section{The levels of prolactin and estradiol serum}

On $14^{\text {th }}$ day and 28th day of the lactation period, lactation rats were adjusted to blood sampling procedure through a lateral tail vein. The blood samples were centrifuged (14,000 rpm, 15 minutes) and serum was stored at $-20^{\circ} \mathrm{C}$. Serum prolactin and estradiol were estimated by enzymelinked immunosorbent assay (ELISA) method. The concentrations of estradiol and prolactin hormones were measured by BT-Laboratory Rat Estrogen EL1SA Kit ${ }^{\circledR}$ (No. E0176Ra) and BT-Laboratory Rat Prolactin EL1SA Kit ${ }^{\circledR}$ (No. E0190Ra).

\section{Extraction of RNA}

The RNA isolation of the mammary gland used RNeasy® Lipid Tissue Mini Kit (Qiagen, Germany), cDNA was obtained by using Transcriptor Synthesis First Stand DNA Kit (Thermo Scientific, Lithuania, EU), and the expression gene receptor used the SYBR Green Select Master Kit (Applied Biosystem, USA). All RNA samples from the mammary glands were extracted using the RNeasy ( ${ }^{\circledR}$ Lipid Tissue Mini Kit method (Qiagen, Germany). Samples (70 mg) were added into nitrogen (N2) liquid, inserted $1 \mathrm{~mL}$ of lysis buffer (QIAzol Lysis Reagent), then crushed with a micropestle and incubated at $25^{\circ} \mathrm{C}$, for 5 minutes. Chloroform $(200 \mu \mathrm{L})$ was added to the sample, mixed for 15 seconds, incubated at $25^{\circ} \mathrm{C}$, for 3 minutes, then centrifuges $12000 \mathrm{rpm}$, at temperature $4^{\circ} \mathrm{C}$, for 15 minutes. Water-soluble phase (500 $\mu \mathrm{L})$ was taken, then added ethanol solvent $(500 \mu \mathrm{L}$, $70 \%)$. A total of samples $(700 \mu \mathrm{L})$ were inserted into $2 \mathrm{~mL}$ RNeasy mini spin column, centrifuge $10000 \mathrm{rpm}$, at $25^{\circ} \mathrm{C}$, for 15 seconds. The solution was discarded, then added RW1 buffer $(700 \mu \mathrm{L})$ into the RNeasy column, centrifuge $10000 \mathrm{rpm}$, at $25^{\circ} \mathrm{C}$, for 15 seconds, the solution was discarded, then added 500 $\mu \mathrm{L}$ RPE Buffer into RNeasy column, centrifuge $10000 \mathrm{rpm}$, temperature $25^{\circ} \mathrm{C}$, for 15 seconds. The solution was discarded, $500 \mu \mathrm{L}$ RPE Buffer was added into RNeasy column, closed, centrifuge $10000 \mathrm{rpm}$, at $25^{\circ} \mathrm{C}$, for 2 
minutes, then placed in $2 \mathrm{~mL}$ RNeasy column tube, centrifuge $14000 \mathrm{rpm}$, temperature $25^{\circ} \mathrm{C}$, for 1 minute. RNeasy column was transferred into tube $1.5 \mathrm{~mL}$, then added RNase free water $(40 \mu \mathrm{L})$, centrifuge $10000 \mathrm{rpm}$, for 1 minute. RNA template obtained is stored at $-80 \mathrm{oC}$ until ready to be analyzed. The quality and quantities of RNA were measured using a spectrophotometer with an OD260/OD280 ratio is 1.9 to 2.1 .

\section{cDNA synthesis of isolated RNA}

The RNA isolated was reverse transcribed into complementary DNA (cDNA) using Transcription Synthesis First Stand DNA Kit method (Thermo Scientific, Lithuania, EU). The solution consists of $2 \mu \mathrm{L}$ RNA template, $1 \mu \mathrm{L}$ oligo (dT) and $9 \mu \mathrm{L}$ water, was incubated at $65^{\circ} \mathrm{C}$ for 5 minutes. Then added $4 \mu \mathrm{L} 5 \times \mathrm{RB}$ (buffer), $1 \mu \mathrm{L}$ riboblock, $2 \mu \mathrm{L}$ $\mathrm{dNTP}$ and $1 \mu \mathrm{L}$ reverse transcriptase, and incubated using polymerase chain reaction (PCR) at $42^{\circ} \mathrm{C}$ and $78^{\circ} \mathrm{C}$, respectively, for 5 minutes. The quantification of cDNA was analyzed using a spectrophotometer (Agilent 8453, USA) with an OD260 / OD280 ratio is 1.8 .

\section{The expression analysis of estradiol and prolac-} tin receptors genes using real-time PCR

The cDNA obtained used for the expression of prolactin (PRLR) and estradiol (ER $\alpha$ ) receptor genes using real time - polymerase chain reaction (RT-PCR) (Analytic Jena, AG qTower 4 channel, Germany). Reaction of real time - PCR using SYBR Green Select Master Kit (Applied Biosystem, USA), i.e.: $10 \mu \mathrm{L}$ mixed reaction used to contain $5 \mu \mathrm{L}$ master mix SybGreen; $0.5 \mu \mathrm{L}$ each forward and reverse primers $(20 \mu \mathrm{M}) ; 1 \mu \mathrm{L}$ cDNA (70 ug/ $\mu \mathrm{L}$ ) of the sample; $3 \mu \mathrm{L}$ nuclease-free water. PCR condition was run at the following: $95^{\circ} \mathrm{C}$ for 5 minutes, 40 cycles at $95^{\circ} \mathrm{C}$ for 10 seconds, followed with $60^{\circ} \mathrm{C}$ for 1 minutes, and $72^{\circ} \mathrm{C}$ for 30 seconds.

The expression of prolactin (PRLR) and estradiol $(E R \alpha)$ receptor gene were calculated based on the relative quantities of mRNA target genes (PRLR and ER $\alpha$ ) with control genes ( $\beta$-actin) by the CT comparison method $(\Delta \mathrm{CT})$. The expression between target genes and control genes can be compared with equation 2- $\Delta \mathrm{CT}$, with delta CT $(\Delta \mathrm{CT})=\mathrm{CT}$ target gene $-\mathrm{CT}$ control gene (housekeeping gene) [22].

Primers were used for housekeeping gene ( $\beta$ - actin) consist of: Forward- 5'GTA AAG ACC TCT ATG CCA ACA'3, Reverse- 5'GGA CTC ATC GTA CTC CTG CT'3; and to amplify the mRNA of PRLR and ER $\alpha$ consists of PPLR: Forward-5'CAA CAT CAG CCT CCT GAA GG'3, Reverse- 5'GTA GTC TGG ACA TTC GTA GG'3; and ERa: Forward- 5'CAG AGA GAT GG TGG GA GG'3, Reverse- 5'GGT TGG TCA ATA AGC CCA TC'3.

\section{Statistical analysis}

Data were presented in mean \pm standard deviation and then tested for normality. All statistical analysis was performed using Microsoft Excel 2013. The differences between treatments were analyzed using ANOVA. Significant differences between mean values were determined using Duncan's Multiple Range Test ( $\alpha=5 \%)$.

\section{Results and Discussion \\ The characteristics of rats}

The characteristics of rat samples used in postpartum interventions are presented in Table 1. Table 1 showed that there were no significant differences between groups of rats sampled from the duration of pregnancy, the number of pups in one birth and birth weight of pups ( $\mathrm{P}>0.05$ ). This is indicated that the sample of rats used in postpartum intervention was homogeneous.

\section{The levels of estradiol and prolactin hormones}

The hormonal system plays an important role in milk production. Based on our previous study, the ethyl acetate fraction of torbangun leaves,

Tabel 1. The average of length of pregnancy, number of pups in once gave birth, and birth weight of pups.

\begin{tabular}{|c|c|c|c|c|c|}
\hline \multirow{2}{*}{ Parameter } & \multicolumn{5}{|c|}{ Group } \\
\hline & $\mathrm{KO}$ & $\mathrm{AF}$ & EA & $\mathrm{AQ}$ & $\mathrm{KP}$ \\
\hline Length (days) & 22.0 & 21.7 & 21.7 & 22.0 & 21.7 \\
\hline $\begin{array}{l}\text { Number of pups } \\
\text { (pups) }\end{array}$ & 8.6 & 9.2 & 8.8 & 8.3 & 9.2 \\
\hline $\begin{array}{l}\text { Birth weight of } \\
\text { pups (g) }\end{array}$ & 8.2 & 8.1 & 7.8 & 7.7 & 7.8 \\
\hline
\end{tabular}

Data are expressed as mean $(n=5)$. KO: control group, AF: commercial milk booster group, EA: ethyl acetate fraction of CA group, AQ: aqueous fraction of CA group, KP: kaempferol group. Data are expressed as mean \pm SE. *shows significant differences $(P<0.05)$. flavonoid kaempferol and commercial milk booster increased milk production $17 \%, 51 \%$, and 


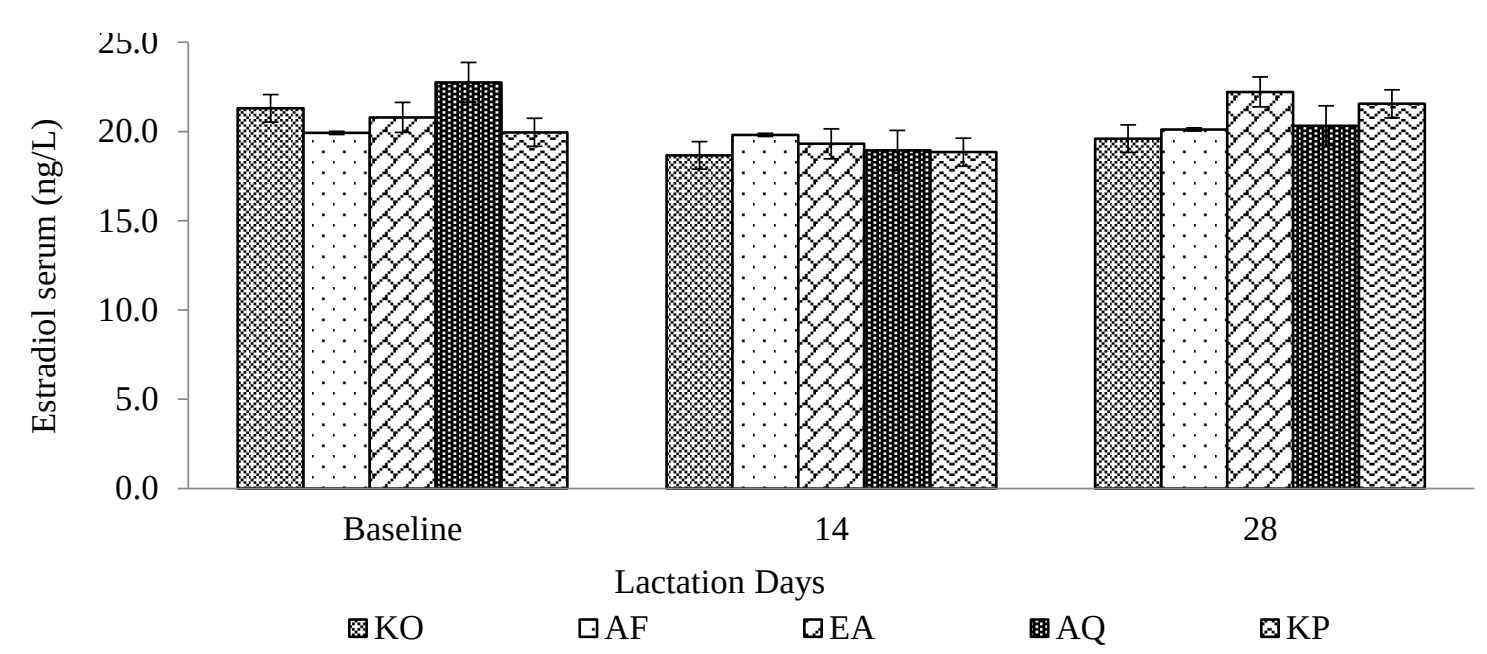

Figure 1. The levels of estradiol of lactating rats during days 14 and days 28. Baseline (days 2 after postpartum before getting intervention). KO: control group, AF: commercial milk booster group, EA: ethyl acetate fraction of CA group, AQ: aqueous fraction of CA group, KP: kaempferol group. Data are expressed as mean \pm SE. *shows significant differences $(\mathrm{P}<0.05)$.

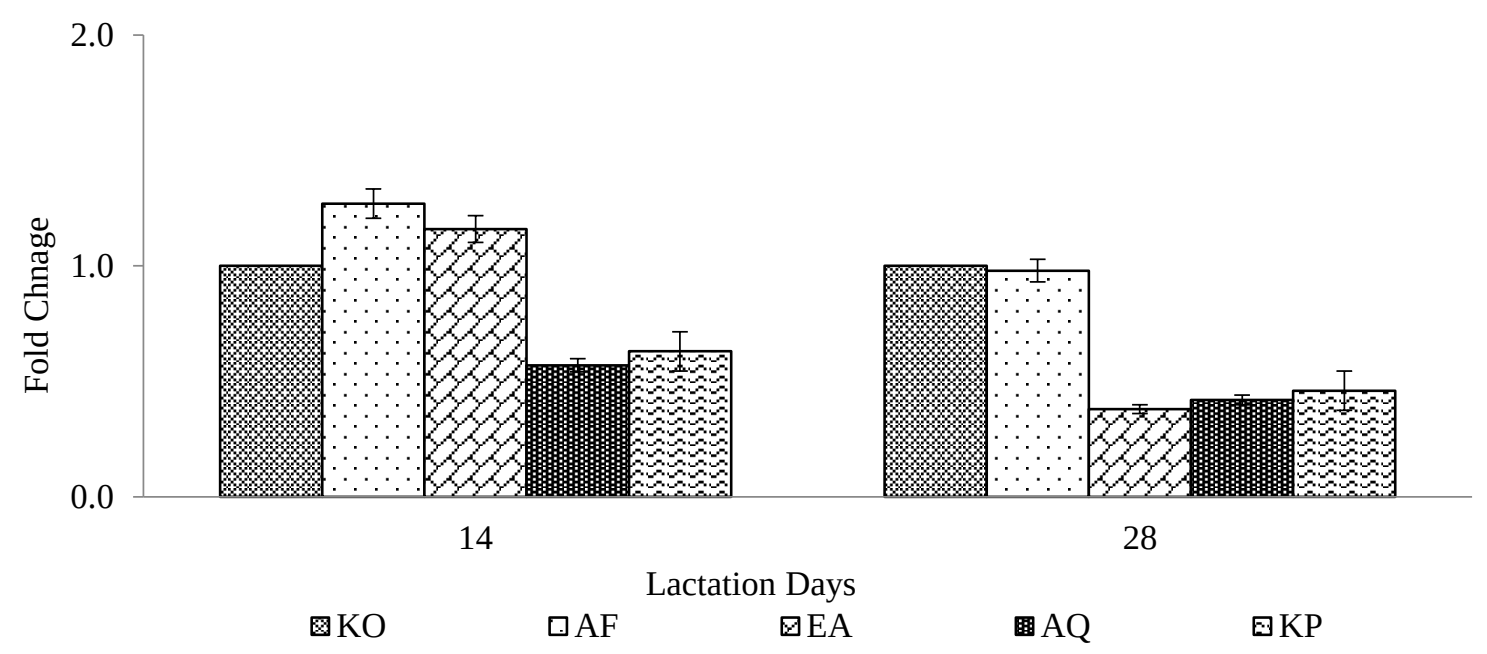

Figure 2. The Expression of the estradiol receptor gene (ER $\alpha)$ of the mammary gland in lactating rats. These are real-time PCR results and fold change is with respect to the housekeeping gene. KO: control group, AF: commercial milk booster group, EA: ethyl acetate fraction of CA group, AQ: aqueous fraction of CA group, KP: kaempferol group. Data are expressed as mean \pm SE. * shows significant differences (P $<0.05)$.

$22 \%$, respectively, compared to the control [6, 23]. According to a study estrogen plays an important role in the growth, differentiation, and function of various types of tissues, especially the mammary glands [24]. The levels of estradiol (E2) hormone serum in lactating rats are shown in Figure 1.

The levels of E2 hormone serum on Day 14 and Day 28 of lactation period were not significantly affected by the administration of the torbangun leaves extract and its fraction $(\mathrm{P}>0.05)$.
The results indicated that the torbangun leaves extract and its fraction, especially bioactive compounds, did not affect the levels of estradiol (E2) hormone in the serum of lactating rats. This can be caused by several factors, such as inappropriate dosage of treatment, it may be that the dosage was used just as limited as antioxidants and were not able to affect estradiol receptors. The concentration levels of flavonoid compounds mainly phytoestrogens, can affect the activity of estradiol receptors. 
The water extract and ethyl acetate fraction of torbangun leaves contained phenolics, flavonoids, and esters [6, 23]. The torbangun leaves extract and its fraction contained quercetin, rutin and kaempferol [5].

Prolactin (Prl) is a polypeptide hormone secreted by the hypothalamus (anterior pituitary). Prolactin has a role in water and electrolyte balance, growth, and development, reproduction, regulation of the immune system and actions related to pathophysiological diseases [26]. According to [14], the regulation of the prolactin hormone in the hypothalamus was affected by estradiol and the administration of estradiol (exogenous) may increase gene transcription and the levels of prolactin mRNA.

Our previous studies [6] shows that the administration of the torbangun leaves extract and its fraction has not affected the levels of prolactin hormone during lactating at Day 14 and Day 28. These results are in disagreement with [27] that reported; the feed fenugreek seeds can increase milk production followed by increased levels of serum prolactin. The difference in these results might be in the extracts, and their fractions of torbangun leaves do not give effect to Estradiol Receptor (ER), so it can not affect the expression of prolactin gene in the hypothalamus. However, the tendency of the prolactin levels decreased with increasing days of lactation.

The increased milk production observed in this study may be due to the ability of bioactive compounds of torbangun leaves to induce expression of prolactin receptor gene, by up-regulation of casein production and lactose synthetase enzyme activity in epithelial cells of mammary glands [28].

\section{The expression of estradiol and prolactin recep- tor genes}

The estrogen receptor is the core receptor of the fat-soluble estradiol (E2) receptor, it caused receptor transformation into a dimmer form and initiate gene transcription where the E2 molecule enters into the cell freely, through the cell wall and binds to the ligand binding domain of the intracellular of estrogen receptor [29].

In this study, the effect of administration of torbangun leaves on the expression of the estradiol receptor gene $(E R \alpha)$ in the mammary gland of lac- tating rats is presented in Figure 2. The results showed that the expression of the estradiol receptor gene $(E R \alpha)$ on the mammary gland of lactating rats on day 14 was not influenced by the bioactive compounds that contained in water extract or ethyl acetate fraction of torbangun leaves $(\mathrm{P}>0.05)$. However, on day 28 of the lactation period, the administration of kaempferol, water extract and ethyl acetate fraction of torbangun leaves influenced the expression response of estradiol receptor gene $(\mathrm{ER} \alpha)(\mathrm{P}<0.05)$. The expression of the estradiol receptor gene down-regulated by an ethyl acetate fraction (0.62-fold), water extract of torbangun (0.58-fold), and kaempferol (0.53-fold) compared to control (Figure 2).

These results indicated that at day 28 during the lactation period, the levels of estradiol hormone differ significantly, and the bioactive compounds (phytoestrogens) of torbangun leaves had estrogenic activity in the mammary glands of lactating rats. According to [30], the estrogenic potential of a component is influenced by several factors, such as the differential effect on the transactivation functionality of the receptor, the involved co-activator, and the promoter of the gene and the target cell. Kaempferol had a lower potency and transactivation activity than the $17-\beta$-estradiol (E2) of ER $\alpha(0.35)$ and ER $\beta$ (0.53) [25].

The prolactin receptor (PRLR) is present in the plasma membrane of each target tissue. In the lactation period, the prolactin and its receptors bind to the mammary glands and can determine the quantity of milk to be produced [12]. According to [31], when the prolactin hormone and its receptors were binding, transcription of the active target genes and biological effects occurs. The average expression of prolactin receptor gene (PRLR) in the mammary gland of lactating rats after administration extract of torbangun leaves and its fraction was shown in Figure 3.

Figure 3 showed that the expression of prolactin receptor gene (PRLR) in the mammary gland on day 14 of lactating rats was influenced by the bioactive compounds that contain in extracts and its fraction of torbangun leaves $(\mathrm{P}<0.05)$. The kaempferol group (KP) showed highest expression of the prolactin receptor gene with 3-fold upregulation by rats during lactation period followed by $\mathrm{AF}$ (2-fold)> AQ and EA (1.5-fold) compared to the control group. Similarly, the commercial milk booster group (AF) showed the highest up- 


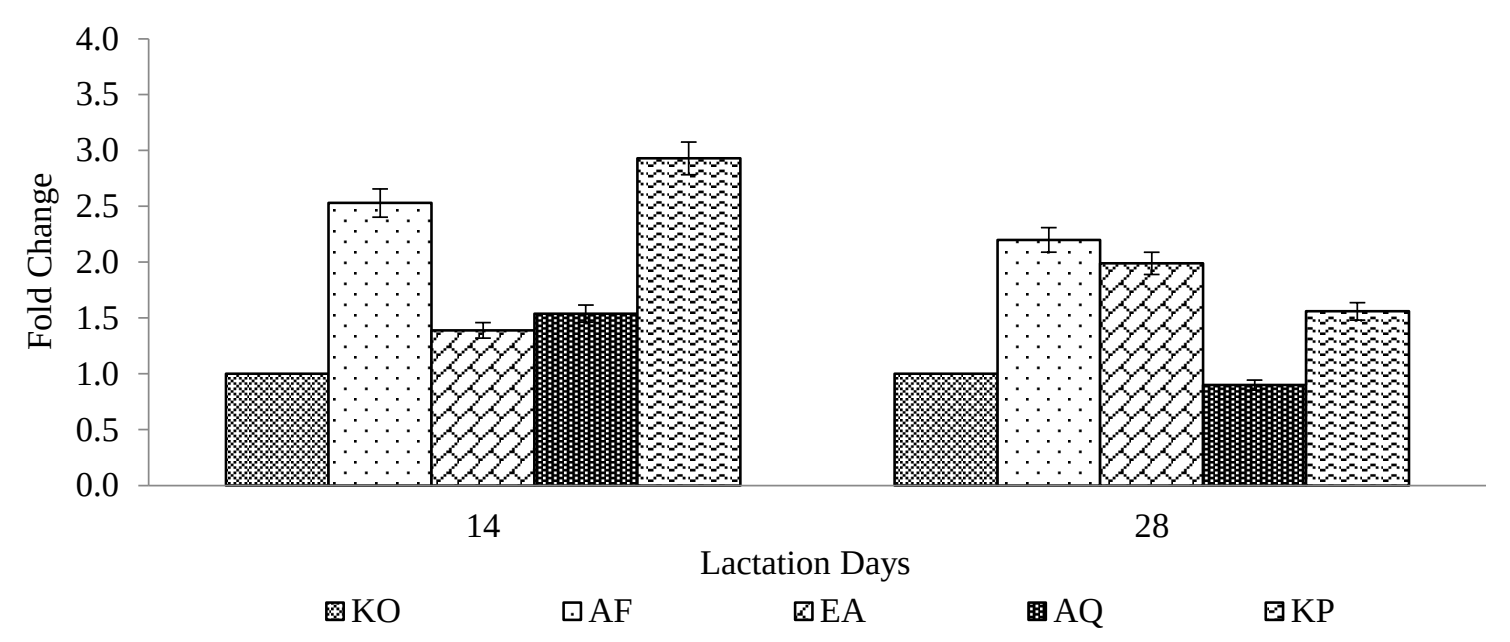

Figure 3. The Expression of the prolactin receptor gene (PRLR) of the mammary gland in lactating rats. These are real-time PCR results and fold change is with respect to the housekeeping gene. KO: control group, AF: commercial milk booster group, EA: ethyl acetate fraction of CA group, AQ: aqueous fraction of CA group, KP: kaempferol group. Data are expressed as mean $\pm \mathrm{SE}$. * shows significant differences $(\mathrm{P}<0.05)$.

Table 2. The summarized results of the expression of the estradiol receptor gene (ER $\alpha)$ and prolactin receptor gene (PRLR) of the mammary gland in lactating rats (Different alphabet shows significant differences $(\mathrm{P}<0.05))$

\begin{tabular}{lcccc}
\hline Treatments & ER $\alpha / \beta$-actin $\left(\mathrm{C}_{\mathrm{t}}\right)$ & Fold change & PRLR/ $\beta$-actin $\left(\mathrm{C}_{\mathrm{t}}\right)$ & Fold change \\
\hline Day-14: & & & & \\
KO & $5.99 \pm 0.65$ & $1.00^{\mathrm{c}}$ & $8.36 \pm 0.55$ & $1.00^{\mathrm{e}}$ \\
AF & $5.65 \pm 0.47$ & $1.7^{\mathrm{a}}$ & $7.02 \pm 0.44$ & $2.53^{\mathrm{b}}$ \\
EA & $5.77 \pm 0.18$ & $1.17^{\mathrm{b}}$ & $7.88 \pm 0.11$ & $1.39^{\mathrm{d}}$ \\
AQ & $6.79 \pm 0.35$ & $0.57^{\mathrm{e}}$ & $7.74 \pm 0.08$ & $1.54^{\mathrm{c}}$ \\
KP & $6.66 \pm 0.44$ & $0.63^{\mathrm{d}}$ & $6.81 \pm 0.23$ & $2.93^{\mathrm{a}}$ \\
& & & & \\
Day-28: & & & & \\
KO & $6.95 \pm 0.63$ & $1.00^{\mathrm{a}}$ & $8.69 \pm 0.18$ & $1.00^{\mathrm{d}}$ \\
AF & $5.98 \pm 0.29$ & $0.98^{\mathrm{b}}$ & $7.60 \pm 0.38$ & $2.13^{\mathrm{a}}$ \\
EA & $8.33 \pm 0.02$ & $0.38^{\mathrm{e}}$ & $7.70 \pm 0.70$ & $1.99^{\mathrm{b}}$ \\
AQ & $8.21 \pm 0.15$ & $0.41^{\mathrm{d}}$ & $8.84 \pm 0.03$ & $0.90^{\mathrm{e}}$ \\
KP & $8.06 \pm 0.22$ & $0.46^{\mathrm{c}}$ & $8.09 \pm 0.09$ & $1.52^{\mathrm{c}}$ \\
\hline
\end{tabular}

regulation of prolactin receptor gene (2.7-fold) followed by EA (2.4-fold)>KP (1.5-fold)>control at day 29 during the lactation period. The results were in agreements with [32], which reported administration of flavonoid "rutin" increased the levels of prolactin hormone and up-regulated the expression of prolactin receptor genes in the mammary gland of vasectomy rats. Moreover, the administration of methanolic extract of torbangun leaves reported increased expression of prolactin receptor gene in MCF-12A cell lines [33].

\section{Conclusion}

Ethyl acetate fraction of torbangun leaves dos- age $30 \mathrm{mg} / \mathrm{kg}$ BW (EA) and kaempferol dosage of $60 \mathrm{mg} / \mathrm{kg}$ BW (KP) did not significantly affect the stimulation of serum prolactin synthesis and estradiol at day 14 and day 28 of the lactation period. On day 28 of the lactation period, bioactive compounds of EA, KP, and AF significantly affected the expression of estradiol receptor genes by down-regulating their expression. Meanwhile, bioactive compounds of EA, KP, and AF affected the expression of prolactin receptor gene (PRLR) by up-regulating their expression on the mammary glands at day 14 and day 28. This study indicates that ethyl acetate fraction of torbangun leaves induced milk production, by down-regulating the 
gene expression of estradiol receptor $(\mathrm{ER} \alpha)$, and up-regulating the gene expression of prolactin receptor (PRLR) in the mammary gland of lactating rats.

\section{Acknowledgment}

The authors are grateful to the Ministry of Research and Technology and Higher Education, Republic of Indonesia (KEMENRISTEKDIKTI-RI) for financial assistance and to Bogor Agricultural University (IPB) and Indonesian Institute of Sciences (LIPI) for providing access and technical support.

\section{References}

1. Zuppa AA, Sindico P, Orchi C et al. (2010) Safety and efficacy of galactogogues: Substances that induce, maintain and increase breast milk production. Journal of Pharmacy and Pharmaceutical Sciences 13 (2): 162 - 174. doi: 10.18433/j3ds3r.

2. Damanik R, Wahlqvist ML, Wattanapenpaiboon N (2006) Lactagogue effects of torbangun, a bataknese traditional cuisine. Asia Pacific Journal Clinical Nutrition 15 (2): 267 - 274. doi: 10.1177/0890334408326086.

3. Santosa CM (2001) Khasiat konsumsi daun bangun-bangun (Coleus amboinicus L) sebagai pelancar sekresi air susu ibu menyusui dan pemacu pertumbuhan bayi. Thesis. Bogor Agricultural University, Postgraduate School.

4. Ministry of Health - Republic of Indonesia (2016) Peraturan Menteri Kesehatan No. 6 tahun 2016 tentang formularium obat herbal asli Indonesia. Jakarta, Ministry of Health - Republic of Indonesia. Pp 1-225.

5. Arumugam G, Swamy MK, Sinniah UR (2016) Review: Plectranthus amboinicus (Lour.) spreng: botanical, phytochemical, pharmacological and nutritional significance. Molecules 21 (4): 3690 - 3695. doi: 10.3390/molecules21040369.

6. Damanik RM, Kustiyah L, Hanafi M, Iwansyah AC (2017) Evaluation lactogenic activity of ethyl acetate fraction of torbangun (Coleus amboinicus L.) leaves. In Proceeding of the ICONPROBIOS Symposium, 23-24 Oktober, 2017, Jakarta, Indonesia. Edited by Wasito R, Tachibana S, Matsunami K et al. doi: 10.1088/1755-1315/101/1/012007.

7. Iwansyah AC, Damanik RM, Kustiyah L, Hanafi M (2016) Relationship between antioxidant properties and nutritional composition of some galactopoietics herbs used in Indonesia: a comparative study. International Journal of Pharmacy and Pharmaceutical Sciences 8 (12): $236 \quad-243 . \quad$ doi: 10.22159/ijpps.2016v8i12.14964.

8. Ye H, Ng HW, Sakkiah S et al. (2016) Pathway analysis revealed potential diverse health impacts of flavonoids that bind estrogen receptors. International Journal of Environmental Research and Public Health 13 (4): 1 - 17. doi: 10.3390/ijerph13040373.

9. Younes M, Honma N (2011) Estrogen receptor $\beta$. Archives of Pathology \& Laboratory Medicine 135 (1): 63 - 66.

10. Paterni I, Granchi C, Katzenellenbogen JA, Minutolo F (2014) Estrogen receptors alpha $(\mathrm{ER} \alpha)$ and beta $(\mathrm{ER} \beta)$ : subtype-selective ligands and clinical potential. Steroids 90: $13-29$. doi: 10.1016/j.steroids.2014.06.012.

11. Eyal O, Jomain JB, Kessler C et al. (2007) Autocrine prolactin inhibits human uterine decasualization: A novel role for prolactin. Biology of Reproduction 76 (5): 777 - 783. doi: 10.1095/biolreprod.106.053058.

12. Saunier E, Dif F, Kelly PA, Edery M (2003) Targeted expression of the dominant negative prolactin receptor in the mammary gland of transgenic mice results in impaired lactation. Endocrinology 144 (6): 2669 - 2675. doi: 10.1210/en.2002221038.

13. Huricaran S, Li Y (2014) STAT signaling in mammary gland differentiation, cell survival and tumorigenesis. Molecular and Cellular Endocrinology 382 (1): 560 - 569. doi: 10.1016/j.mce.2013.03.014.

14. Maurier RA (1982) Estradiol regulates the transcription of the prolactin gene. The Journal of Biological Chemistry 257 (5): $2133-2136$

15. Hiroi R, Handa RJ (2013) Estrogen receptor-regulates human tryptophan hydroxylase-2 through an estrogen response element in the 5' untranslated region. Journal of Neurochemistry 127 (4): 487 - 495. doi: 10.1111/jnc.12401

16. Slominski A, Semak I, Pisarchik A et al. (2002) Conversion of l-tryptophan to serotonin and melatonin in human melanoma cells. FEBS Lett., 511: 102-106.

17. Gorski K, Hasiec M, Zielinska-Gorska M, Fulop F, Misztal T (2017) Up-regulation of oxytocin receptor gene and protein in the sheep anterior pituitary by a dopamine derivative (salsolinol). Czech Journal of Animal Science 62 (4): 150 - 156. doi: 10.17221/30/2016-CJAS

18. Sajimin ND, Purwantari E, Sutedi, Oyo (2011) Effect of cutting interval to productivity and quality of bangun-bangun (Coleus amboinicus L.) as a forage promising commodity. Jurnal Ilmu Ternak dan Veteriner 16 (4): 288 - 293.

19. Andarwulan N, Yuliana ND, Hasna E et al. (2014) Comparative analysis of three torbangun clones (Plectranthus amboinicus (Lour.) spreng) based on phenotypic characteristics and phenolic content. American Journal of Plant Sciences 5 (24): 3673 - 3683. doi: 10.4236/ajps.2014.524383.

20. Frederer WT (1967): Experimental design: Theory and application. Calcutta (IN), Oxford \& IBH Publ. Co. Pp 591.

21. Silitonga M (1993) Efek laktogogum daun jinten (Coleus amboinicus L) pada tikus laktasi. Thesis. Bogor Agricultural University, Postgraduate School. 
22. Schmittgen TD, Livak KJ (2008) Analyzing real-time pcr data by the comparative ct method. Nature Protocols 3 (6): 1101 1108. doi: 10.1038/nprot.2008.73.

23. Iwansyah AC, Damanik RM, Kustiyah L, Hanafi M (2017) Potensi fraksi etil asetat daun torbangun (Coleus amboinicus L.) dalam meningkatkan produksi susu, bobot badan induk dan anak tikus. Jurnal Gizi Pangan 11 (3): 61 - 68. doi: 10.25182/jgp.2017.12.1.61-68.

24. Korach KS, Migliaccio S, Davis VL (1994) Estrogens. In: Munson PL (ed) Principles of pharmacology-basic concepts and clinical applications.New York (US), Chapman and Hall. Pp $809-825$.

25. Kuiper GGJM, Lemmen JG, Carlsson B et al. (1998) Interaction of estrogenic chemicals and phytoestrogens with estrogen receptor $\beta$. Endocrinology 139 (1): 4252 - 4263. doi: 10.1210/en.139.10.4252.

26. Bole-Feysot C, Goffin V, Edery M, Binart N, Kelly PA (1998) Prolactin and its receptor: actions, signal transduction pathways and phenotypes obsereved in prl receptor knockout mice. Endocrine Reviews 19 (3): 225 - 268. doi: 10.1210/edrv.19.3.0334.

27. Janabi AK (2012) Feeding effect of fenugreek seeds (Tringonella foenum-graceum) on lactation performance, some serum constituents and prolactin hormone level in damascus crossbred goats. Diyala Agricultural Sciences Journal 4 (1): 1 -8 .
28. Tabares FP, Jaramillo JVB, Ruiz-Cortes ZT (2014) Pharmalogical overview of galactagogues. Veterinary Medicine International 2014: 1 - 20. doi: 10.1155/2014/602894.

29. Denger S, Reid G, Brand H (2001) Tissue specific expression of human er-alpha and er-beta in male. Molecular Cellular Endocrinology 178 (1 - 2): 151 - 160. doi: 10.1016/S03037207(01)00417-8.

30. Brzozowski AM, Pike ACW, Dauter Z et al. (1997) Molecular basis of agonism and antagonism in the oestrogen receptor. Nature 389: 753 - 758. doi: 10.1038/39645.

31. Freeman ME, Kanyicska B, Lerant A, Nagy G (2000) Prolactin: structure, function, and regulation of secretion. Physiological Reviews $80 \quad$ (4): $1523 \quad-\quad 1631$. doi: 10.1152/physrev.2000.80.4.1523.

32. Guo XD, Diao QY, Wang YY et al (2012) The effect of administration of rutin on plasma levels of estrogen, prolactin, growth hormone and gene expression of their receptors in mammary glands in ovariectomized rats. Journal of Integrative Agriculture 11 (10): 1700 - 1706. doi: 10.1016/S2095-3119(12)60173-7.

33. Tafzi F, Andarwulan N, Giriwonob PE, Dewid FNA (2017) Efficacy methanol extract of torbangun leaves (Plectranthus amboinicus) in epithelial cell of mammary gland MCF-12A. Jurnal Ilmu Kefarmasian Indonesia 15 (1): 17 - 24. 